\title{
Dinamika Budaya Material pada Desain Furnitur Kayu di Indonesia
}

\author{
Arianti Ayu Puspita, Agus Sachari, Andar Bagus Sriwarno \\ Institut Teknologi Bandung \\ Jl. Ganesha no.10, Bandung 40132
}

\begin{abstract}
The impact of Indonesia economic development in 21st century, then the increasing needs of furniture both from outside and within the country, and the development of design in Indonesia, are directly related to ecological problems. The high demand for wood encourage furniture industry in Indonesia to use alternate various kinds of solid wood, wood processing and wood waste. Wood has a role in the dynamic cultural development of Java, both from the aspect of spiritual, philosophical, aesthetic and economic. This study aims to describe the shift in social and cultural values that occurred on the island of Java, in particular the use of wood materials. The development of wood utilization will be explained based on Material Cultural Studies viewpoint. Sustainable and ecologicalconcept for furniture design in Indonesia would be seen as an opportunity to maintain the continuity of wood materials.
\end{abstract}

Keyword: cultural transformation, furniture, wood, Indonesia, ecology

\begin{abstract}
ABSTRAK
Perubahan kondisi ekonomi hingga abad ke-21, dan meningkatnya kebutuhan furnitur baik dari luar maupun dalam negeri, kemudian perkembangan ilmu desain di Indonesia, secara tidak langsung berhubungan dengan permasalahan ekologi. Ketersediaan sumber daya alam seperti kayu, semakin berkurang sehingga mendorong industri furnitur di Indonesia untuk menggunakan alternatif berbagai macam kayu solid, kayu olahan hingga kayu limbah. Dari waktu ke waktu, perubahan kondisi sosial, ekonomi, dan gaya hidup, turut berperan pada kemunculan bentuk-bentuk furnitur baru di Indonesia. Pada penelitian ini, transformasi kebutuhan material kayu pada furnitur akan dikaitkan dengan dinamika sosial budaya yang terjadi dari abad ke-18 hingga abad ke-21 di Indonesia. Tansformasi akan dilihat berdasarkan perubahan teori Material Cultural Studies, yang kemudian akan menghasilkan kesimpulan bahwa konsep ekologi berperan penting dalam perkembangan desain furnitur kayu di Indonesia.
\end{abstract}

Kata kunci: transformasi budaya, furnitur, kayu, Indonesia, ekologi 


\section{PENDAHULUAN}

Kayu merupakan bahan mentah yang mudah diproses untuk dijadikan barang lain. Indonesia memiliki kekayaan variasi jenis kayu didukung dengan letak geografis dan faktor cuaca. Dengan kemajuan teknologi, kayu dapat diolah menjadi berbagai produk seperti kertas, tektil, furnitur dan sebagainya. Kayu mempunyai sifat-sifat spesifik yang tidak bisa ditiru oleh bahan lain buatan manusia. Misalnya, kayu mempunyai sifat elastis, ulet, tahan terhadap pembebanan dan berbagai sifat lain lagi yang tidak dimiliki beton, baja hingga plastik. Ciri-ciri umum kayu dapat dilihat dari Sifat fisiknya. Kasmudjo (2012) menyebutkan bahwa karakter pada sifat fisik sebuah kayu berkaitan dengan apa yang dilihat langsung oleh mata, yang termasuk di dalamnya adalah; warna kayu (termasuk serat kayu), bau, kesan raba (termasuk tektur), kilap, kekerasan dan berat.

Sudah sejak lama masyarakat Indonesia memiliki keterikatan dan pengetahuan lokal yang mendalam pada material kayu. Contohnya pada Masjid Demak yang didirikan tahun 1466, seluruh bahan baku yang digunakan berupa kayu jati. Salah satu tiang penyangganya ada yang terbuat dari serpihan kayu Jati (tatal). Selain perwujudannya pada tempat ibadah dan tempat tinggal, keterikatan yang kuat pada material kayu juga diperlihatkan pada karya pengrajin ukir di Jepara.Dikatakan oleh Zamroni (2004), setelah kebudayaan Islam masuk ke Nusantara, penggunaan kayu menjadi ramai, khususnya kayu Jati. Kayu jati (tectona grandis) adalah jenis kayu keras yang banyak dimanfaatkan untuk kebutuhan pasar dalam negeri dan ekspor. Berdasarkan tingkat kebutuhannya, kayu adalah material yang mendominasi penggunaan produk furnitur di Indonesia, yaitu sebanyak 67,02\% (Majalah Furnicraft Today, Departemen Perindustrian \& Perdagangan Republik Indonesia, 2014).

Furnitur saat ini tumbuh menjadi barang komoditi, sehingga pertimbangan desain tidak hanya berkaitan dengan aspek budaya namun juga aspek ketersediaan bahan baku, tingkat kemampuan ekonomi masyarakat dan potensi industri. Effendi dan Dwiprabowo (2007) mengatakan, bahwa bahan baku kayu merupakan salah satu faktor yang menentukan keunggulan

Tabel 1: Tabel Ekspor Furniture 2014, Berdasarkan Bahan Baku

\begin{tabular}{clrr}
\hline No. & Deskripsi & Nilai (USD) & Prosentase \\
\hline 1 & Wooden Furniture & 1.259 .224 .080 & $67.02 \%$ \\
2 & Rattan Furniture & 17.781 .750 & $9.19 \%$ \\
3 & Bamboo Furniture & 2.129 .645 & $0.11 \%$ \\
4 & Metal Furniture & 45.821 .375 & $2.43 \%$ \\
5 & Plastic Furniture & 62.640 .158 & $3.33 \%$ \\
6 & Other & 336.185 .603 & $17.89 \%$ \\
\hline & Jumlah & 1.878 .782 .612 & $100 \%$ \\
\hline
\end{tabular}

(Sumber: Majalah Furnicraft Today, 2015) 
komparatif dari industri furnitur dan memberikan kontribusi utama dalam menentukan biaya produksi.

Dengan melihat sejarah masa lalu, maka konon penggunaan material kayu telah lama dimanfaatkan sejak abad ke-8 di Indonesia, khususnya pulau Jawa. Bahkan sejak VOC mengalami kebangkrutan pada abad ke-18, pulau Jawa mulai mengalami kelangkaan material kayu khususnya Jati. Dengan kurun waktu yang sangat lama, Indonesia mengalami banyak perubahan dan perkembangan baik itu dari kondisi politik, ekonomi, sosial dan budaya. Hal tersebut juga turut mempengaruhi keadaan alam dan lingkungan hutan di Indonesia karena pengambilan hasil hutan.

Pada perkembangan kehidupan manusia, peradaban manusia semakin modern dan dipengaruhi oleh pengetahuan dari kelompok manusia itu sendiri. Pengaruh tersebut juga membawa perubahan pada kondisi lingkungan manusia. Dengan kebudayaannya, manusia dapat mengolah dan mempengaruhi kondisi lingkungan (Djajadiningrat, 2005: 17), seperti yang terjadi pada pemanfaatan material alam dalam pengolahan furnitur. Perkembangan desain furnitur kayu di Indonesia tidak terlepas dari perubahan nilai sosial budaya, nilai ekonomi, dan isu lingkungan yang menyertainya. Karena itu, pada penelitian ini akan disusun sintesa antara peralihan kebutuhan material kayu pada furnitur, dengan nilai sosial budaya dan isu lingkungan yang menyertainya.

\section{METODE}

Metode yang dilakukan adalah studi literatur dengan pendekatan kualitatif dan paparan deskriptif. Paparan data disusun dan dijelaskan dengan metode historikal. Material Cultural Studies menjadi bingkai utama untuk menjelaskan peralihan nilai sosial budaya pada furnitur kayu di Indonesia. Salah satu ahli budaya arkeologi di Indonesia bernama Vogler menyebutkan bahwa perubahan dalam nilai estetika terjadi karena adanya perpaduan gaya. Menurutnya, setiap komponen memiliki riwayat perjalanan, dan tidak hanya ditemukan pada satu contoh saja (Sedyawati, 2010: 37). Furnitur kayu dapat menjadi salah satu studi kasus dalam mengkaji identitas budaya Indonesia. Pengumpulan data dilakukan melalui kajian literatur perkembangan jenis material kayu pada furnitur sebelum abad 19 dan kumpulan sampel desain furnitur setelah abad 20 di Indonesia. Kemudian kemunculan berbagai jenis kayu tersebut dikaitkan dengan nilai sosial-ekonomi yang mempengaruhinya. Setelah itu, akan ditarik benang merah yang dapat menghubungkan antara kondisi sosial budaya yang mengiringi perkembangan penggunaan kayu pada abad ke-18 hingga abad ke-21. "Benang merah" tersebut merupakan kemungkinan, nilai estetika yang dapat berkembang dan menjadi jawaban akan kebutuhan material kayu di masa depan.

A. Material Cultural Studies dan Furnitur Kayu sebagai Objek

Untuk memahami proses perubahan penggunaan material kayu beserta nilai sosial budaya yang menyertainya, maka dibutuhkan sebuah pendekatan disiplin. Objek pada Material Cultural Studies adalah sesuatu yang berperan, berinteraksi dan digunakan oleh manusia. Objek memiliki lingkup yang luas, namun tidak termasuk pada natural objek seperti alam seperti batu, air, pohon, tulang, fosil dan sebagainya. Batasannya adalah pada objek buatan manusia atau hasil modifikasi manusia. Menurut Prown (1982), budaya material (material culture) adalah kajian melalui 
kepercayaan nilai pada artifak, konsep, tanggapan masyarakat pada suatu waktu tertentu. Objek dapat mengalami perubahan waktu, perubahan bentuk dan perubahan nilai namun masih merupakan jenis objek yang sama. Objek menjadi sumber utama data, dan budaya material menjadi alat dalam menelusuri nilai budayanya. Budaya material mengalami perubahan yang disebabkan oleh faktor internal dan eksternal. Faktor internal terletak pada unsur manusia itu sendiri yang memiliki insting selalu ingin berubah ke arah yang lebih baik (Sumiati, 2015:31). Sedangkan faktor eksternal selalu mendorong adanya perubahan dalam nafas kehidupan (Sumiati, 2015:31), contohnya yaitu faktor ekonomi, faktor gaya hidup, faktor lingkungan, dan sebagainya. Prown (1982:1) menyatakan bahwa material cultural studies merupakan alat dalam penelitian budaya, namun memiliki tujuan akademis sebagai cabang dari sejarah kebudayaan atau antropologi budaya. Premis utama adalah objek merupakan hasil karya manusia, secara sadar maupun tak sadar, langsung maupun tidak langsung. Objek tersebut sekaligus merupakan wujud keyakinan dan digunakan manusia dan berpengaruh terhadap keyakinan sekelompok masyarakat tempat mereka berada. Woodward (2007:7) mengatakan bahwa Material Cultural Studies (MCS) menganalisa dan menghubungkan pengetahuan klasik dan modern dari suatu objek melalui pandangan sosial budaya. Hubungan antara manusia dengan objek pada kajian MCS sangat erat yang terkait dengan: (1) perbedaan status dan budaya; (2) identitas personal dan sosial dan (3) narasi sosial di masyarakat. Hal ini ditekankan oleh pernyataan dari Bourdieu (1984) seperti yang dikutip oleh Woodward (2007:15), bahwa konsep suatu objek dapat menjadi penanda nilai estetika, nilai budaya dan identitas diri. Hal ini terkait dengan objek pada penelitian, bahwa konsep furnitur yang berkembang dengan visi ekologi dapat menjadi penanda nilai estetika baru.

\section{HASIL DAN PEMBAHASAN}

A. Kebutuhan Material Kayu untuk Furnitur Sebelum Abad ke-20

Sejak abad ke-17, kehadiran produk furnitur di Pulau Jawa Tengah bertujuan untuk memenuhi kebutuhan fungsional, sosial dan estetika di lingkungan kerajaan (Kraton). Furnitur yang digunakan di lingkungan Kraton dikaitkan dengan nilainilai filosofis, dimana bentuk visual yang sangat indah di dalamnya dinilai mengandung nilai-nilai budaya adiluhung. Furnitur milik raja sering diidentikkan dengan sosok raja itu sendiri. Material yang banyak digunakan adalah kayu Jati, yang mana kayu Jati memiliki nilai filosofis pada budaya masyarakat Jawa. Kayu Jati dianggap sebagai kayu prima, karena karakternya yang kuat, mudah digunakan dan mudah beradaptasi dengan material lainnya. Selain itu, memiliki karakter yang pionir karena mampu tumbuh di tanah yang tidak subur. Karena sifat fisiknya yang sangat baik, masyarakat Jawa menganggap kayu Jati sebagai keinginan paling inti (sejati) dari manusia. Nilai tersebut juga dipengaruhi oleh aspek spiritual masyarakat, berdasarkan ajaran agama dan leluhur, sesuatu yang bernilai harus diperlakukan dengan hati-hati.

Selain untuk konstruksi bangunan dan furnitur, material kayu digunakan dalam berbagai keperluan, misalnya untuk menumbuk padi, mainan anak Sultan, senjata, dan hantaran pernikahan. Berdasarkan pengamatan penulis, maka material kayu adalah bahan yang dapat digunakan untuk berbagai jenis aktivitas di 
Keraton pada masa lalu, mulai dari aktivitas sederhana yang dilakukan para abdi keraton hingga kegiatan ritual keraton yang dilakukan oleh anggota kerajaan. Furnitur di dalam keraton tidak hanya mengutamakan fungsi kebutuhan semata, namun juga memiliki nilai-nilai simbolis dan nilai estetis. Awalnya, jenis kayu yang banyak digunakan untuk furnitur di Pulau Jawa adalah Macassar Ebony (Diospoyros celebica), Ambon Merah (Pterocarpus indicus), Sonokeling (Dalbergia latiforia) dan kayu Jati (Tectona grandis) (Veenendaal: 1985). Keempat jenis kayu tersebut memiliki kelebihan dari segi kekuatan, keindahan serat, ketahanan, dan nilai sosialnya. Masing-masing kayu memiliki kelebihannya masing-masing. Contohnya kayu Ebony, yang memiliki permukaan halus dan licin, dan serat yang lurus. Sedangkan kayu sonokeling memiliki permukaan mengkilap, sehingga berkesan mewah.
Pada masa pemerintahan Sultan Pakubuwana X di Kesultanan Surakarta Hadiningrat (1893-1939), furnitur kayu menjadi bagian dari aktivitas diplomasi kenegaraan. Bangsa lain seperti Cina, Spanyol dan Belanda memberikan furnitur kayu untuk keluarga kerajaan sebagai simbol kerjasama. Seiring dengan berjalannya waktu, penggunaan material kayu dipengaruhi oleh perkembangan teknologi pada abad ke-19, khususnya pada Revolusi Industri. Revolusi industri di Inggris yang merupakan usaha masinalisasi teknik produksi yang sebelumnya masih menggunakan teknik manual.

Dengan adanya peristiwa revolusi industri, banyak dihasilkan desain-desain yang mengutamakan faktor efisiensi dan mengurangi unsur dekoratif. Louis Sullivan pernah mengeluarkan pernyataan yang terkenal, yaitu Form Follow Function. Kemudian pernyataan tersebut disempurnakan oleh Frank Llyod Wright
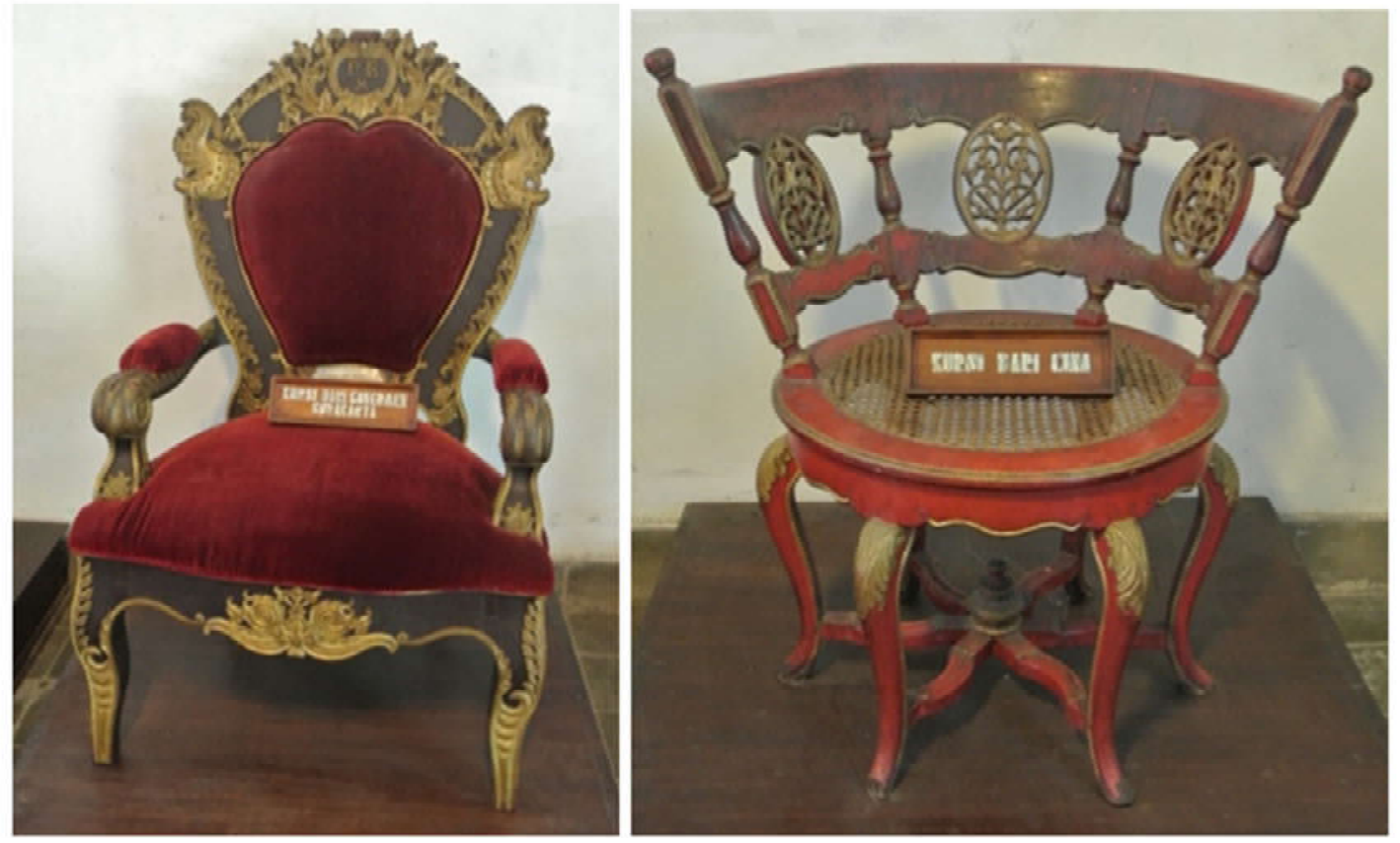

Gambar 1.

Pemberian bangsa lain (Pemerintah Belanda \& Cina) pada masa pemerintahan Sultan Paku Buwono $X$

(Sumber: Koleksi Furnitur Keraton Surakarta Hadiningrat, 2015) 
menjadi Form and Function are One. Revolusi industri secara langsung meningkatkan hasil produksi furnitur kayu. Salah satu contoh desain kursi yang memiliki pengaruh global pada fenomena industrialisasi adalah kursi Thonet, yang memiliki kelebihan dari aspek efektivitas material dan efisiensi pengemasan barang. Di Indonesia, keterampilan dalam kerajinan ukir dan membuat furnitur semakin berkembang. Kemunculan kursi sebagai simbol kemuliaan diperkenalkan oleh bangsa Eropa, sehingga banyak digunakan oleh kalangan kerajaan, bangsawan dan bangsa lain di Indonesia di abad ke-18 hingga abad ke-19. Kemunculan masyarakat kelas menengah yang mampu membeli furnitur dengan desain baik dan harga terjangkau, semakin banyak, sehingga permintaan akan furnitur juga semakin tinggi. Tingginya permintaan furnitur menyebabkan tingginya tingkat penebangan hutan, baik di Indonesia ataupun di seluruh dunia.

B. Kebutuhan Material Kayu untuk Furnitur Setelah Abad ke-20

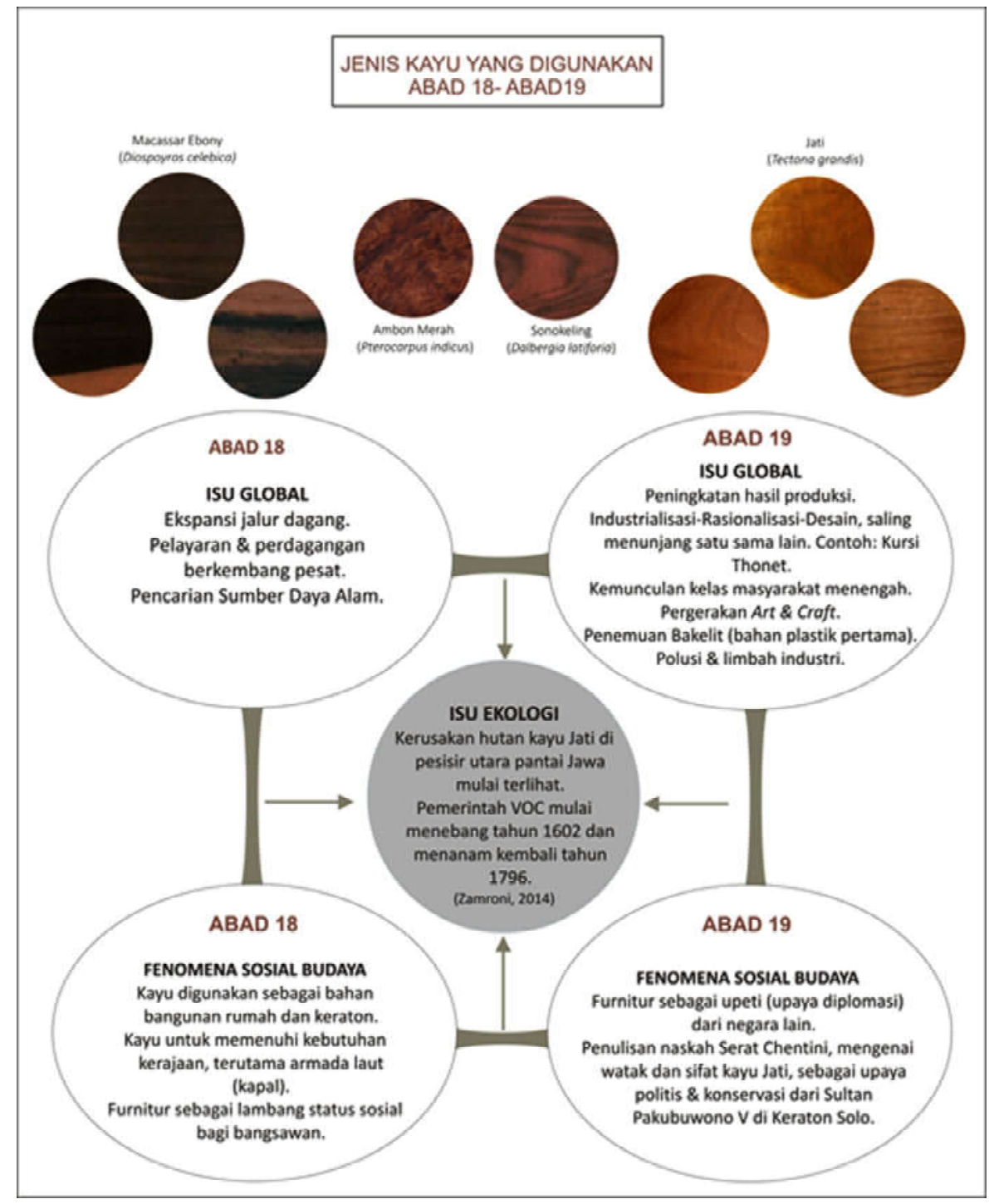

Gambar 2:

Gambaran interpolasi terhadap jenis kayu solid yang digunakan pada abad 18-19 untuk furnitur

(Sumber: Arianti A.P, 2015) 
Pada perkembangan paradigma desain di abad ke-20, terdapat wacana-wacana yang turut mempengaruhi perubahan desain pada furnitur, baik itu dari segi gaya desain ataupun penggunaan materialnya. Berbagai paradigma desain tersebut sangat berpengaruh terhadap perkembangan industri seni kerajinan tangan pada umumnya dan industri furnitur ukir khususnya, yang berlangsung hingga awal abad ke-20.Jenis alternatif kayu solid yang digunakan setelah abad ke-20 terus bertambah, tidak hanya menggunakan kayu berkualitas tinggi seperti Ebony, Ambon merah, Sonokeling dan Jati karena jenis-jenis kayu tersebut sudah sulit untuk didapatkan dan harganya sangat tinggi. Beberapa alternatif kayu solid lainnya yang saat ini banyak digunakan adalah kayu Jati muda atau Gmelina (Gmelina arborea), Mindi (Melia azedarach), Mahoni (Swietenia spp.), Akasia (Acacia mangium Will), Pinus (Pinus merkusii), dan Sungkai (Peronema canescens). Menurut Mansur
(2015), berbagai alternatif kayu tersebut memiliki masa panen yang lebih singkat, dapat dipanen sejak umur 10-15 tahun. Namun, tentu saja jenis kayu alternatif tersebut memiliki karakter fisik, kekuatan dan ketahanan yang berbeda dengan jenis kayu berkualitas tinggi. Karena itu bentuk desain dan nilai estetis yang dihasilkan juga memiliki karakter berbeda dengan jenis kayu di gambar 2 .

Seiring dengan perkembangan zaman, maka dinamika perubahan budaya turut mempengaruhi kehidupan bermasyarakat. Pada masa sekarang, furnitur tidak lagi dijadikan media diplomasi seperti yang dilakukan sebelum abad ke-20 di lingkungan Keraton. Namun, furnitur telah menjadi produk komoditas yang mengutamakan aspek fungsional (utilitarian). Perbedaan status sosial masih ada, namun tidak sekental pada masa lalu, ketika sebuah furnitur dapat menunjukkan tingkat derajat sosial seseorang. Kehidupan yang semakin demokratis, pemikiran yang maju
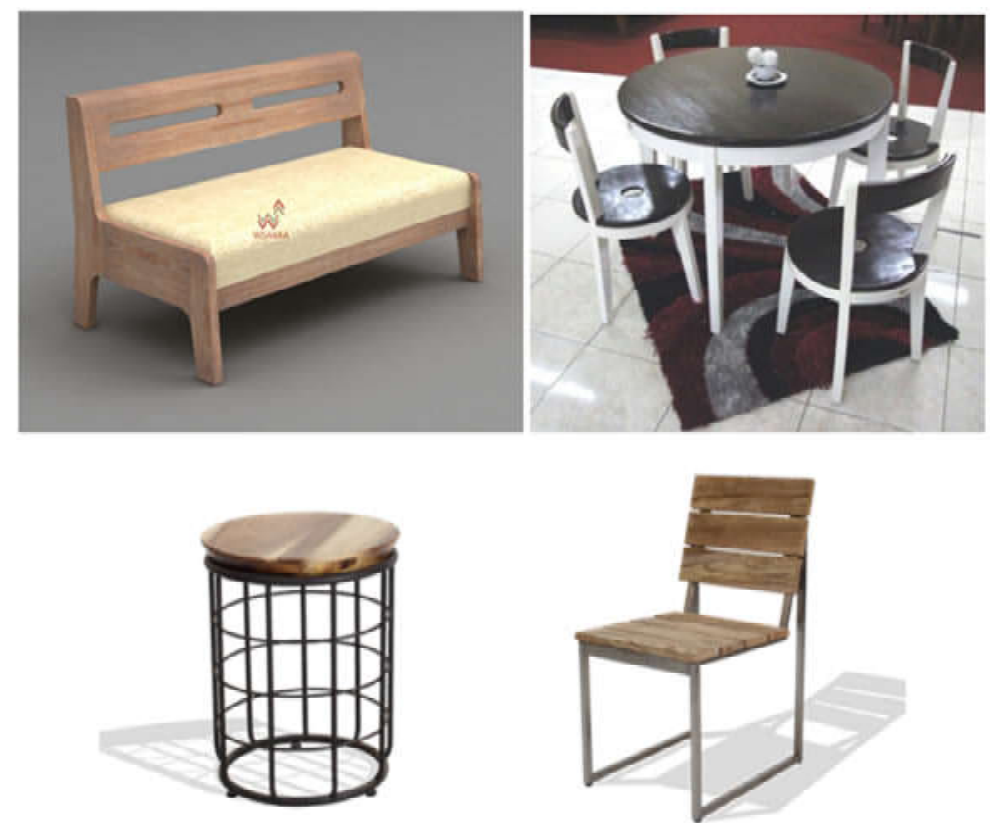

Gambar 3:

Berbagai karakter desain furnitur dari Wisanka Furnitur (atas) \& Yudhistira Furnitur (bawah) saat ini (sumber: Website Wisanka \& Website Yudhistira, 2015) 
mempengaruhi peningkatan kemampuan ekonomi masyarakat. Pada abad ke-20, muncul jenis-jenis furnitur yang semakin mudah diproduksi dengan mempertimbangkan aspek kesederhanaan bentuk dan sistem lepas pasang (knock down).

Sejak tahun 1980 hingga sekarang, kayu olahan banyak digunakan. Antara lain seperti kayu lapis (tripleks \& multipleks), partikel kayu (chipboard standar, veneer chipboard dan OSB (oriented strand board)), papan serat kayu (medium density fiber board) dan kayu "plastik". Disebutkan oleh Jamaludin (2014:87), terobosan utama furnitur pada abad ini sangat tergantung pada kemajuan teknologi dan material. Munculnya furnitur dengan pertimbangan fungsi dan ekonomi juga dipengaruhi oleh tingginya kebutuhan masyarakat saat ini. perkembangan kegiatan industri furnitur di Indonesia dipengaruhi salah satunya dipengaruhi oleh aspek proses produksi yang terdiri dari desain, material, teknik, peralatan, diversifikasi dan fungsi produk

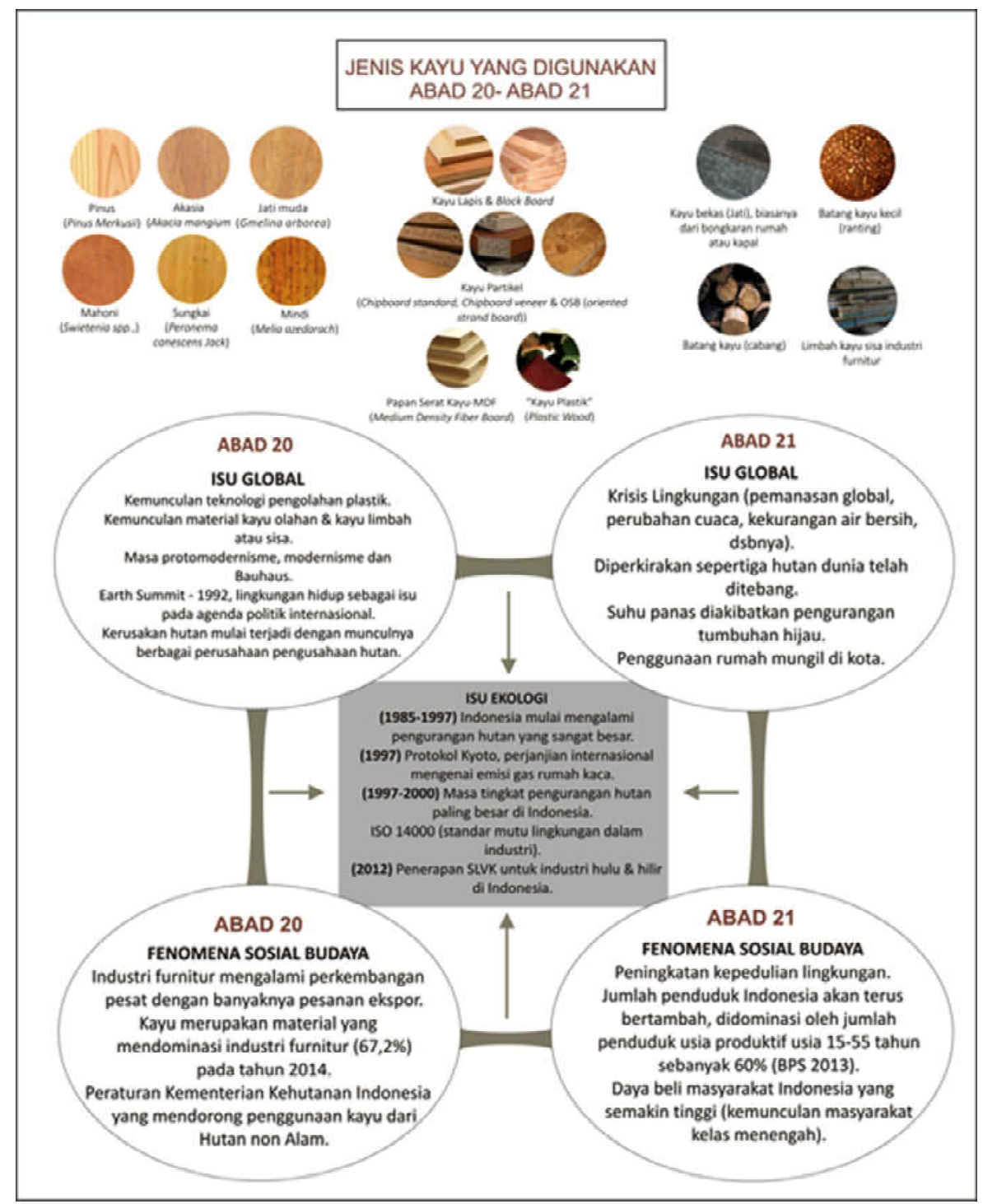

Gambar 4:

Gambaran interpolasi terhadap jenis kayu solid, kayu limbah \& kayu olahan yang digunakan untuk furnitur setelah abad ke-20

(Sumber: Arianti A.P, 2015) 
(Gustami, 2009:208). Kebutuhan bahan kayu terutama kayu Jati semakin banyak, sehingga para pengrajin dan industri mulai mencari jenis kayu lain sebagai alternatif. Pada tahun 1928 di Indonesia, ketertarikan terhadap jenis kayu lain ditunjukkan antara lain dengan adanya furnitur yang terbuat dari mozaik beraneka macam kayu, yaitu antara lain kayu sana, kayu mentahos, kayu nangka, kayu sawo dan kayu secang (Gustami, 2009:216).

Penggunaan alternatif material kayu solid semakin berkembang, baik untuk keperluan ekspor maupun produk dalam negeri karena permintaan akan furnitur dari luar negeri semakin deras. Produk-produk yang dikonsumsi untuk kepentingan ekspor umumnya menggunakan kayu Jati, kayu eben dan kayu mahoni. Sedangkan untuk produk non ekspor lebih banyak menggunakan kayu jati, nangka, durian, jering, kayu sengon, sungkai dan lainnya yang tergolong kayu keras (Gustami, 2000: 211). Banyaknya kebutuhan akan material kayu memancing isu lingkungan hidup yang turut mempengaruhi perkembangan desain furnitur. Saat ini telah banyak furnitur yang dihasilkan melalui pemanfaatan kembali kayu bekas (re-use) dan pengolahan limbah industri (recycle).

\subsection{Nilai Ekologi sebagai Arah}

Pengembangan Desain Furnitur Kayu

A. Isu Lingkungan pada Material Kayu

Isu lingkungan hidup mulai muncul setelah konferensi PBB di Stockholm, Swedia 5-16 Juni 1972 mengenai lingkungan hidup manusia (United Nations Conference on Human EnvironmentUNCHE) yang diikuti 113 negara. Ketika itu isu utama lingkungan ditengarai karena keterbatasan dan penyusutan sumberdaya alam yang tersedia. Perhatian terhadap lingkungan saat ini membuat pandangan ekologi menjadi filosofi baru, yang dijadikan patokan ideal bagi masyarakat yang memperhatikan ekologi. Berdasarkan laporan dari Forest Watch Indonesia 2013, sekitar 73 juta hektare luas tutupan hutan alam di Indonesia terancam oleh kerusakan yang lebih besar di masa yang akan datang, baik yang disebabkan aktivitas penebangan dan konversi lahan yang terencana, akses terbuka (open access) terhadap lahan, serta ketidakhadiran pengelola di tingkat tapak. Tidak hanya di Indonesia, isu lingkungan juga telah menjadi permasalahan global.

Melalui bagan pada Gambar 2 dan Gambar 4, terlihat bahwa perkembangan desain furnitur kayu sangat dipengaruhi oleh isu lingkungan hidup.Permintaan pasar yang sangat tinggi menyebabkan tingginya kebutuhan kayu di Indonesia. Kayu adalah material alam yang dapat diperbarui, namun kegiatan deforestasi dan penebangan kayu yang berlebihan dapat mengurangi jumlah dan hasil hutan. Menurut data dari Forest Watch Indonesia, tingkat pengurangan hutan paling besar di Indonesia dimulai pada tahun 1970 dan memuncak pada tahun 1997-2000 yaitu 2,84 juta hektare per tahun. Kini, tanggung jawab terhadap pemanfaatan hasil hutan tidak hanya berada pada pihak pemerintah, namun juga pada setiap pelaku yang memanfaatkan kayu, termasuk industri furnitur. Dibutuhkan strategi yang baik pada tiap industri untuk dapat memanfaatkan kayu secara efisien dan tepat guna sehingga juga memberi manfaat terhadap kelangsungan hutan.

\section{B. Budaya Ekologi}

Konsep ekologi muncul sebagai respon dari hubungan manusia dengan lingkungan. Kebudayaan yang terbantuk terjadi berdasarkan adaptasi manusia terhadap lingkungan (Steward, 1955). Agar dapat terus bertahan hidup dan mempertahankan 
lingkungannya, maka manusia melakukan proses adaptasi. Steward mengutip dari Webster, berdasarkan istilah biologi, pengertian ekologi adalah hubungan saling ketergantungan antara organisme dengan lingkungannya, dalam hal ini adalah manusia dengan lingkungan. Budaya ekologi (ecology culture) mengkaji bagaimana pengaruh adaptasi terhadap lingkungan pada kebudayaan. Pendekatan historikal dapat dilakukan dalam menganalisa asal usul suatu produk budaya dalam konsep ekologi. Pendekatan pada aspek ekologi kini masuk ke berbagai bagian bidang studi baik itu desain maupun teknikal, sebagai tanda bahwa peran sustainability sangat besar untuk masa depan.

\section{Desain Produk Berkelanjutan (Sustainability)}

Diegel (2010) mengutip Whiteley (1993) yang menyebutkan dalam “Design for Society", desainer memiliki kewajiban moral untuk bertanggung jawab terhadap desain mereka, dan pengaruh sosial dan lingkungan yang menjadi dampaknya. Telah banyak metode yang dihasilkan pada berbagai penelitian, untuk memberikan metode untuk desain produk yang berkelanjutan. Tokoh yang mengawali konsep desain berkelanjutan, Victor Papanek memaparkan 6 aspek dalam sistem produksi yang menjadi dasar dalam menciptakan produk berkelanjutan (1995:29) dalam "The Green Imperative", yaitu:

1. Pemilihan material: pemilihan material dilakukan dengan seksama oleh desainer dan pihak industri. Pertimbangan ini penting untuk menjaga kelestarian dan menghemat energi.

2. Proses produksi: pertanyaan kepada desainer adalah apakah ada hal dalam proses produksi yang dapat membahayakan tempat kerja dan pekerjanya, seperti polusi atau bahan radio aktif.

3. Kemasan: pemilihan kemasan dilakukan atas dasar kemudahan untuk diurai, seperti menghindari material plastik, styrofoam dan sebagainya.

4. Finished Product: tingginya tingkat persaingan antara industri furnitur saat ini mengakibatkan adanya eksploitasi terhadap material kayu secara berlebihan, dengan membuat varian yang beraneka macam dari satu jenis produk.

5. Transportasi atau distribusi: semakin panjangnya proses distribusi, maka energi bahan bakar yang digunakan semakin banyak.

6. Akhir siklus produk (waste) : apakah produk dapat digunakan atau diolah kembali.

Metode lain yang juga mempertimbangkan aspek desain berkelanjutan dikeluarkan oleh UNEP (United Nations Environment Programme Division of Technology, Industry and Economics) yang bekerja sama dengan Delft University of Technology pada tahun 2006, disebut D4S (Design for Sustainability).Terdapat 7 aspek desain yang harus dipertimbangkan pada strategi D4S, antara lain adalah:

(1 penggunaan material ramah lingkungan,

(2) efisensi penggunaan material,

(3) teknik produksi,

(4) sistem distribusi,

(5) pengaruh ketika pemakaian,

(6) jangka waktu pakai, dan

(7) akhir siklus produk.

Terdapat aspek lain yang perlu dilengkapi pada strategi D4S, yaitu aspek kreatif pada proses desain, sebelum 
terjadinya proses produksi. Tujuan terhadap produk berkelanjutan sebaiknya berada pada tiap bagian produk, termasuk tahap mendesain. Pada proses mendesain, kreativitas desainer dalam melakukan inovasi dan brainstorming sangat penting sebagai awal perancangan produk. Strategi desain dibutuhkan karena setiap jenis material memiliki karakter yang berbeda, terutama kayu bekas atau kayu limbah, yang perlakuannya juga berbeda dengan kayu baru.

\section{Strategi Desain Furnitur Kayu berdasarkan Budaya Ekologi}

Berbagai aspek desain berkelanjutan yang telah disebutkan sebelumnya, beberapa di antaranya memiliki kesamaan. Oleh karena itu, penulis akan mencoba menyaring dan menyusun kembali aspekaspek desain berkelanjutan yang dapat diterapkan pada pengembangan desain produk, termasuk furnitur kayu. Aspek ini akan menjadi dasar; hal apa saja yang perlu dipertimbangkan untuk menerapkan budaya ekologi pada sebuah desain. Terdapat 13 aspek yang perlu dipertimbangkan, yaitu:

1. Pemilihan material;

Desainer harus dapat memikirkan baikbaik material apakah yang akan digunakan. Sebaiknya, material yang digunakan adalah material yang tidak berbahaya, material yang dapat diperbarui, atau material baru yang muncul berdasarkan inovasi teknologi.

2. Estetika;

Faktor estetika dapat dipengaruhi oleh banyak hal, misalkan faktor eidetic (kemampuan mengingat visual secara detail), dan biosocial given (berdasarkan pengaruh estetika pada lingkungan seharihari atau keluarga). Kemudian dapat dipengaruhi faktor persepsi dan gestalt.
3. Sosial Budaya;

Desain pada sebuah furnitur juga dapat terwujud berdasarkan perilaku atau kebiasaan yang telah melekat pada masyarakat tersebut. Misalkan desain sebuah kursi amben di Jawa, yang dapat digunakan untuk berbagai kegiatan oleh lebih dari 1 orang. Sebuah furnitur juga sebaiknya dapat memancing agar penggunanya memiliki perilaku ekologi. Misalnya, pengguna dapat memanfaatkan kembali furnitur yang tidak terpakai menjadi produk dengan fungsi baru.

4. Proses produksi;

Dalam proses produksi, dampak polusi dan limbah yang dihasilkan juga perlu dipikirkan agar dapat mengurangi bahaya terhadap lingkungan sekitar.

5. Umur produk;

Beberapa desain furnitur klasik dapat memperpanjang umur penggunaan produk. Selain itu, kemudahan dalam penggunaan dan perawatan produk juga menjadi faktor bagi pengguna untuk meningkatkan ikatan dengan produk tersebut. Tanpa disadari, produk yang disukai dan memiliki ikatan kuat dengan penggunanya, tidak akan dengan mudah dibuang dan ditinggalkan.

6. Konsekuensi;

Konsekuensi berkaitan erat dengan hampir semua aspek desain dan proses produksi. Pemilihan material memberikan kelebihan namun sekaligus terdapat kekurangan pada setiap jenisnya. Lingkungan sosial di area industri juga harus dipertimbangkan sebagai lingkungan yang perlu dijaga agar dapat beradaptasi di tengah masyarakat.

7. Produk akhir;

Pada produk akhir, penggunaan bahan 
finishing pada kayu sebaiknya menggunakan bahan yang tidak beracun, terutama apabila disentuh oleh manusia. Industri juga dapat berpartisipasi dalam memberi wawasan kepada konsumennya melalui cara-cara tertentu agar pengguna mengetahui bagaimana cara merawat furnitur kayu dengan baik menggunakan bahan-bahan alami. Terkadang industri memberikan varian yang sangat banyak, walaupun jenis produknya satu, didorong oleh alasanpemasaran dan ekonomi. Namun, varian banyak tersebut tidak dapat mendukung budaya ekologi pada pengembangan desain karena tidak efisien dan menghabiskan material yang cukup banyak hanya untuk satu fungsi yang sama.

8. Fungsi;

Produk yang memiliki lebih dari 2 fungsi dapat memberikan nilai lebih kepada konsumen. Selain memberikan manfaat, juga meningkatkan kesenangan pengguna terhadap produk tersebut. Oleh karena itu, fungsi yang tepat dapat memberikan manfaat bagi budaya ekologi, baik itu produk yang multifungsi, modular, knockdown, maupun flat pack furnitur.

9. Transportasi/ sistem distribusi;

Sistem distribusi juga mempengaruhi budaya ekologi pada desain furnitur. Semakin banyak muatan yang dimasukkan ke dalam kontainer/truk, maka semakin sedikit energi yang dihabiskan. Agar furnitur dapat lebih banyak dimuat, maka strategi desain harus dipikirkan dengan teliti, dari segi struktur furnitur, dimensi, dan bentuknya. Bentuk geometris dan pipih dapat menghemat ruang.

10. Efisiensi;

Mengurangi, menghemat dan mem- perkecil penggunaan kayu merupakan salah satu cara yang dapat dilakukan pada desain berkelanjutan. selain efisiensi terhadap material, efisiensi energi produksi juga menjadi salah satu aspek yang penting. Misalnya, meningkatkan penggunaan energi yang terbarukan, terutama yang berasal dari matahari, air dan angin.

11. Kemasan;

Kemasan sebaiknya digunakan dalam jumlah yang wajar, tidak berlebihan.

12. Siklus produk;

Sejak awal konsep perencanaan, produk dapat digunakan kembali di akhir siklus (re-use), atau diolah kembali (recycle), atau dimodifikasi (upgrading).

13. Servis desain;

Servis desain dapat menggantikan bentuk fisik sebuah produk, sehingga mengurangi pemakaian material dan energi.

\section{SIMPULAN}

Melalui gambaran dimensi interpolasi dan ekstrapolasi, penulis berusaha membaca, memperkirakan perkembangan sifat-sifat bentuk desain yang dihasilkan dari berbagai jenis kayu baik itu kayu solid maupun kayu olahan. Berbagai karakter desain yang dihasilkan dapat menjadi alur perkembangan teknologi pada inovasi desain furnitur. Selain kayu baru, ternyata banyak industri yang menggunakan kayu bekas bongkaran rumah hingga kayu limbah dalam memperpanjang siklus material kayu itu sendiri. Melalui pemilihan material yang tepat, kemudian dilakukan berbagai strategi desain untuk menghasilkan furnitur yang diterima oleh masyarakat dengan pijakan desain berkelanjutan. Penulis mengambil kesimpulan bahwa dalam dimensi ekstrapolasi pada masa depan, dibutuhkan strategi desain 
furnitur kayu dengan pijakan desain berkelanjutan, dengan tuntutan kondisi lingkungan dan keterbatasan sumber daya alam. Indonesia memiliki banyak keanekaragaman jenis kayu, namun tantangan yang dihadapi oleh desainer adalah bagaimana dapat memaksimalkan manfaat dari material yang dipilih, dengan memaksimalkan jangka waktu pemakaian dan meningkatkan nilai desain (value) dari furnitur yang dirancang.

\section{Daftar Pustaka}

Diegel, Olaf

2010 Tools for Sustainable Product Design: Additive Manufacturing. Journal of Sustainable Development, Vol 3 No 3, September 2010.

Edi Sedyawati

2010 Budaya Indonesia-Kajian Arkeologi, Seni dan Sejarah. Jakarta: Rajawali Press.

Forest Watch Indonesia

2014 Potret Keadaan Hutan Indonesia Periode 2009-2013. Bogor: Forest Watch Indonesia.

Fuad Luke, Alastair

2009 Design Activism, Beautiful Strangeness for A Sustainable World. London: Eartchscan, p.39.

Irdika Mansur

2015 Bisnis \& Budidaya 18 Kayu Komersil. Jakarta: Penebar Swadaya.

Indah Septi \& Agus Sachari

2007 Pergeseran Gaya Estetis Mebel di Keraton Nyayogyakarta Hadiningrat. Jurnal Visual and Art, Institut Teknologi Bandung, Vol 1 No 1, 85107.

Kasmudjo

2012 Mebel dan Kerajinan, Teori Dasar dan Aplikasi. Yogyakarta: Cakrawala Media.

Kementerian Perindustrian, Republik Indonesia.

2015 Menyongsong Masa Emas Industri Furnitur dan Kerajinan Indonesia. Furnicraft Today, 16-17.
Muhammad Zamroni

2014 Jati Jawa,Kontribusi Kayu Jati bagi Masyarakat Jawa. Jurnal Seni Budaya, Volume 12 no.1.

Papanek, Victor

1995 The Green Imperative, Ecology and Ethics in Design and Architecture. United Kingdom: Thames and Hudson.

Prown, Jules David

1982 Mind in Matter: An Introduction to Material Culture Theory and Method. Winterthur Portfolio, Vol 17 No.1, pp.1-19, The University of Chicago Press.

Rahmat Effendi \& H. Dwiprabowo

2007 Kajian Pengembangan Industri Furniture Kayu melalui Pendekatan Kluster Industri di Jawa Tengah. Jurnal Penelitian Sosial dan Ekonomi Kehutanan Vol.4, No.3 September 2007, hlm. 233-255.

S.P, Gustami

2000 Seni Kerajinan Furnitur Ukir Jepara, Kajian Estetik Melalui Pendekatan Multidisplin. Yogyakarta: Kanisius.

Surna Tjahja Djajadiningrat

2005 Sustainable Future - Menggagas Warisan Peradaban Bagi Anak Cucu Seputar Wacana Pemikiran. Jakarta: Indonesia Center for Sustainable Development (ICSD).

Sumiati, Lilis

2015 Purpose of Art dan Kontribusinya Dalam Transformasi Budaya (Studi Kasus: Tari Jayengrana). Jurnal Ilmiah Seni \& Budaya Panggung Vol 25 no.1 Maret 2015.

Steward, Julian

(-) The Concept and Method of Cultural Ecology. p.319-332.

UNEP in collaboration with Delft University of Technology

2006 Design for Sustainability: A Global Guide. Paris: UNEP.

Woodward, Ian

2007 Understanding Material Culture. London: Sage. 
Veenendaal, Jan

1985 Furniture from Indonesia, Srilanka and India During The Dutch Period.Delft, Netherlands: Volkenkundig Museum Nusantara.

Produk kombinasi kayu dan besi dari Yudhistira Furniture di Solo, Jawa Tengah , www.yudhistira.go.id, diakses 8 September 2015

\section{Sumber lain}

Meja belajar anak (produk Olympic) berbahan particle wood., http://tipe rumah.com/desain-meja-belajar-anakminimalisterbaru/meja-belajar-olympic-furniture-murah/, diakses 8 September 2015 